\title{
Marrying out of the lower classes in nineteenth-century Belgium
}

\author{
BART VAN DE PUTTE*, MICHEL ORIS $\uparrow$ AND \\ KOEN MATTHIJS:
}

\begin{abstract}
In this article we address one of the most prominent questions in historical sociology: did economic modernization in the nineteenth century lead to societal openness? In an attempt to answer the question we examine the chances for lowerclass grooms of marrying upwardly in five Belgian cities (Aalst, Leuven, Ghent, Verviers, and Liège). Our findings show that there is no support for a meritocracy hypothesis. The chances of marrying out of the lower classes did not increase, in either absolute or relative terms. Social closure strategies were efficient in that they apparently prevented upward marital mobility for lower-class grooms. As these findings were measured in a highly advanced economic context, this study casts strong doubts on the relationship between economic modernization, meritocracy, and marital mobility, at least for the nineteenth century.
\end{abstract}

Searching for happiness, finding security, contracting an alliance, conforming to social norms, the choice of a marriage partner is a key moment in each individual's life. But most important for this study is that through marriage, group boundaries are reinforced, so that the study of marriage offers the possibility of examining the claim that economic modernization has led to societal openness. That means that achieved positions - such as one's own social position - rather than ascribed positions - such as one's social origin - are used to evaluate people. ${ }^{1}$ In this article we shall examine openness in terms of the social origin of grooms and brides, and we shall distinguish among five classes: the unskilled, the

* Department of Sociology, Ghent University.

$\dagger$ Department of Economic History and Laboratory of Demography and Family Studies, University of Geneva.

\#Center for Sociological Research, Catholic University of Leuven. 
semi-skilled, the skilled (together forming the lower class), the middle class, and the elite.

On the one hand, societal openness might be prompted by a change in social structure, such as the rise of a 'new' middle class. For the lower classes, then, the presence of a large middle class might have stimulated absolute upward marital mobility. However, in contradiction to that claim it can be argued that due to the proletarianization of the 'old' middle class and agricultural decline, the middle class shrank, so that the possibilities for upward marital mobility decreased.

On the other hand, economic modernization might have changed the preferences and criteria used for partner selection. While during the ancien régime it was explicitly seen as an ideal that horizontal alliances such as marriage should respect vertically inherited social status, ${ }^{2}$ the triumphant nineteenth-century bourgeoisie imposed an ideology of individual merit and competition, which meant that upward and downward marital mobility became increasingly possible. In contradiction to that claim, meanwhile, it can be argued that social closure - which is the process by which certain people are excluded from participation in social groups, for example by using criteria such as race, language, religion, geographical, or social origin - did not fade away in the nineteenth century, and even that it was renewed as new social or demographic classes were formed by the agglomeration into the marriage market of different subgroups of the lower classes.

In this article we address both absolute and relative marital mobility. By 'absolute marital mobility' we mean the actual number of marriages that unite people from different social backgrounds. The number of such mixed marriages is the product of both social structure and people's individual preferences. By 'relative marital mobility' we mean the amount of mobility, but this time controlled for the effect of the social structure, so that the evolution of relative mobility measures tells us whether people's preferences and criteria really did change. We have made the latter our focus, as it is particularly the relationship between economic modernization and relative mobility that is deemed to be the central issue in modernization research. ${ }^{3}$

We shall test the relationship between economic modernization and societal openness by analysing the chances for individuals from lowerclass backgrounds of marrying out of their class. In our opinion, upward marital mobility of the lower classes offers the most important test of trends in marriage partner selection, because two competing claims - societal openness as against social closure - both predict an increase of intermarriage within the lower classes, while only the former predicts intermarriage among all classes. A key issue therefore is whether societal openness was 
strong enough to increase the likelihood for the lower classes of overcoming the barrier between them and the middle classes in the marriage market of the nineteenth century.

We must emphasize, however, that in assessing upward the marital mobility of the lower classes we wish simply to measure the chances for individuals from lower-class backgrounds of crossing social boundaries through marriage. We do not claim that the new couple thereby necessarily ended up forming a middle-class or elite household.

We have located our analysis in the growing urban world of the time. We examined marriage certificates from five Belgian cities, namely the two early industrial textile cities of Ghent and Verviers; the mining and engineering city of Liège; Aalst, which was a late-industrial textile city; and Leuven, which was non-industrial. Those cities are not a representative sample, as they represent some of the most modern economies of the nineteenth century, but the database from them allows us to address classic theories about the relationship between economic modernization and societal openness or closure. We would even go so far as to claim that if societal openness and meritocracy are not to be observed in those cities, they are unlikely to be observed anywhere in the nineteenth century, in so far as one links economic modernization and meritocracy.

\section{MARITAL MOBILITY IN THE NINETEENTH CENTURY}

\subsection{Absolute marital mobility}

This section begins with a discussion of absolute marital mobility. A central question in the discussion is about the composition of the middle class. Most scholars would probably agree that the middle class is composed of three main groups: the petty bourgeoisie, who were skilled manual self-employed people, retailers, or small business owners; farmers, who together with the petty bourgeoisie formed the old middle class; and skilled non-manual workers such as clerks, lower managers - in fact the 'new' middle class. ${ }^{4}$

Nineteenth-century transitions meant changes in both the size and the composition of the middle class, even though many regional differences remained. ${ }^{5}$ One of the first changes was the decline of the old middle class. According to Marxist writers, the proletarianization of the old middle class led to an ever-increasing lower class. The decline of agriculture might have had similar consequences. But as time went on the middle class became dominant. Indeed, artisans emphasized the commercial dimension of their activities, and the whole trade sector, from the most modest shops to the new Grand Bazaar department store, grew impressively in size and 
diversity within the urban world. ${ }^{6}$ Post-industrial theory has further claimed that a new managerial and administrative class and qualified technical and professional staff emerged with the rise of big companies and government institutions. ${ }^{7}$ Industrial societies became middle-class societies.

The changing size and composition of the middle class could well have had important consequences for marriage patterns. In terms of absolute mobility, a decrease or an increase in the size of the middle class might have led respectively to a decrease or increase in the possibility of the lower classes marrying into the middle class. Even though that need not necessarily have affected relative mobility, it could have brought with it important consequences for group formation, because intermarriage by definition unites people from different origins, whether forced by a change in social structure or not. Where proletarianization and agricultural decline were strong in a particular region, for the lower classes the chance of upward marital mobility declined, but where the rise of the new middle class was strong enough that increased the chances of upward mobility for the lower classes. The latter view echoes the Lipset and Zetterberg hypothesis on intergenerational mobility, which claims that during industrialization intergenerational mobility rates increase due to the increasing size of the middle class. ${ }^{8}$

Because of the sometimes very different evolution of social structures in different contexts, the lack of a comparative class scheme, ${ }^{9}$ and the focus on relative marital mobility and on the global pattern of marital, rather than upward, mobility among the lower classes, previous research on absolute upward marital mobility has not provided many results directly compatible with the aim of our research.

We would like to summarize this discussion on absolute marital mobility by distinguishing between the proletarianization and agricultural decline hypotheses, which together claim that absolute upward marital mobility decreased for individuals from lower-class backgrounds, and the 'new middle class' hypothesis, which suggests that absolute upward marital mobility increased.

\subsection{Relative marital mobility}

Economic modernization did not affect only absolute marital mobility. According to the liberal theory of industrialism, that change was accompanied by an increase in equal opportunities, and it is often believed that the rise of the new middle class offered new career possibilities for children born to lower-class families. The recruitment policy of the new institutions was governed by principles of rational bureaucratic selection 
and achievement. Education played a more important part in determining an individual's career. In short, a meritocratic society was on the rise, it seemed. ${ }^{10}$

According to that thesis, social mobility rose, and that view can be translated into terms of marital mobility. It is often believed that modern societal openness was visible in patterns of open partner selection too, as social origin apparently no longer played such a major role in determining opportunity. Moreover, other factors supported the trend towards societal openness, namely the rise of partner selection based on 'romantic' considerations and new, less 'controlled' meeting opportunities such as could be found in pubs or dancehalls. ${ }^{11}$

Nevertheless, some important doubts remain. First, previous empirical research has not confirmed the thesis. Although hampered by constraints similar to those on research into absolute mobility, the conclusion of research in many countries seems to be that there was no general trend towards greater societal openness. ${ }^{12}$ Second, early industrial society was different from mature twentieth-century industrial society, in which, for example, the educational system was fully developed. In the nineteenth century, given the very low level of democratization of the educational system at the time, increased social mobility through educational attainment was not easy. ${ }^{13}$

All that then brings us to formulate alternative hypotheses. We start by presenting these alternatives in general terms. First, proletarianization and agricultural decline may also have resulted in relative marital mobility. In contrast to the previous section, we do not refer here to the quantitative decrease of the (old) middle class, but to qualitative characteristics. For example, proletarianization and agricultural decline may have weakened the economic position of the petty bourgeoisie and of farmers, while not necessarily transforming them into lower-class groups.

Second, it can be expected that neither the middle class nor the elite allowed the lower class to compete on easy terms for good positions. ${ }^{14}$ Social closure may have been a strong obstacle to upward mobility, ${ }^{15}$ and not only in traditional society. Related to that is the idea that demographic lower-class formation determined partner-selection patterns. ${ }^{16}$ Demographic class formation is an example of social-class formation, the formation of social ties between members of a class, irrespective of the specific subgroup they belong to (such as the social formation of a lowerclass group which consists of individuals belonging to the unskilled, the semi-skilled, or the skilled groups). Following that idea, the late nineteenth century gave rise to the unification of the different subcategories of the lower classes on the marriage market, while intermarriage with the middle class did not increase. ${ }^{17}$ 
In the remainder of this theoretical introduction we shall address these hypotheses in more depth by discussing differences in marital mobility patterns according to social position, type of city, migration status, and so on. Discussion of them will guide our empirical analysis of relative marital mobility as we believe that the differences in marital mobility patterns measured through these variables will inform us more clearly about the precise mechanisms underlying societal openness or closure and help us to define the necessary control variables. Among these variables, we distinguish between structural societal factors, personal characteristics, and marriage-related factors.

\section{Structural factors}

The socioeconomic context is the ultimate structural factor influencing the relative likelihood of upward marital mobility. Two important characteristics are the sector composition of the economy (industrial or otherwise; administrative and commercial functions or not; the size of the agricultural sector) and its organizational principles (proletarianization; bureaucratization). That socioeconomic context exerted its influence through proximate characteristics, the first of which is the composition of the middle class. To evaluate their influence we discuss the main subgroups.

The old middle class - the petty bourgeoisie and farmers - were, like any propertied class, anxious not to ruin their property. Furthermore, their desire to protect their respectability led to a large social distance from the lower class, ${ }^{18}$ but there were some factors which facilitated social interaction with them. The petty bourgeoisie, specifically master artisans, might naturally have had the closest links with the lower classes, working side by side with skilled workers. In the course of the nineteenth century both groups might even have become virtually identical. Proletarianization during the second industrial revolution threatened many old urban craft sectors ${ }^{19}$ leading to societal openness, as the amount of social power held by that section of the middle class - power to a large extent based on property - was reduced so that it increasingly resembled the lower class.

The situation of farmers was somewhat peculiar. People with a farming background were not typically part of the city's core group. In our database, most sons and daughters of farmers were migrants whose migration to the city was usually the result of their threatened social position in a context of demographic pressure and land division. In the second quarter of the nineteenth century, and in its final decades especially, the Belgian agricultural sector was in crisis, so children of farmers could be at risk of downward marriage (but see the discussion of migrants in the next 
section). In short, proletarianization and agricultural decline seem to have threatened the social power of the old middle class.

The position of the new middle class is perhaps more difficult to assess. The barrier between non-manual and manual workers could be quite difficult to breach, ${ }^{20}$ but recruitment into the non-manual section of the middle class was arranged by bureaucratic, rational selection procedures - at least in theory. ${ }^{21}$ If so, that group would have been the one most likely to adopt meritocratic values, and might have been the one most open to intermarriage with some elements of the lower class - that is, in cases where a lower-class individual was upwardly mobile in his or her 'bureaucratic' career.

A second characteristic concerns the conditions for class formation, which could vary substantially in different cities. ${ }^{22}$ From the perspective of social closure it is important to stress that industrial cities typically show stronger lower-class cohesion, and that was possibly reflected in a strong aversion on the part of the middle class towards the lower class. ${ }^{23}$ Therefore, one might have expected intermarriage between people from lower-class and middle-class backgrounds to have been less frequent in cities such as Ghent, Liège, Verviers, or, somewhat later, Aalst. Yet, according to the economic modernization perspective, societal openness should be strongest in cities combining modern industrial development with large administrative functions - both sectors are the ones most typically associated with modern bureaucratic recruitment and promotion policies. It was in cities such as Ghent or Liège, then, that societal openness should have increased most rapidly.

\section{Personal characteristics}

Personal characteristics too can enhance upward mobility. First, there are characteristics related to an individual's own position that might be beneficial. Upward intergenerational mobility is, of course, an important tool for attracting a partner from a higher level. ${ }^{24}$ Similarly, being raised in a literate family rather than in one lacking the basic ability even to engage in a written culture must have improved anyone's chances of upward marriage. ${ }^{25}$ In our view, literacy and participation in literate culture are together a clear marker of social status. This can be used as a means to distinguish the 'good' or 'civilized' members of the lower class. ${ }^{26}$ The question is whether upward intergenerational mobility and literacy were sufficient to counter the impact of social origin on marital mobility. If they were not, that would strongly support the idea that social closure is strong enough to counter meritocracy.

Second, the 'respectability' and social power of lower-class parents are important. We can, evidently, expect that children of skilled workers would 
have had greater opportunities to intermarry with the middle class than did the children of semi-skilled workers, or of unskilled ones even more so. Furthermore, those elements of the lower class belonging to the native 'core of the city population' were perhaps the first to intermarry with the middle class. In contrast to men and women from rural backgrounds they might have been more accustomed to the manners and culture of the middle class. ${ }^{27}$ Therefore, if only migrants from rural backgrounds failed to intermarry, while migrants from non-rural backgrounds did intermarry, that would suggest that practical barriers induced by migration were not the only reasons why migrants had less chance of upward marital mobility. Social closure on cultural grounds was a much more likely explanation in their case. ${ }^{28}$

Yet all the same, it seems that at times immigrants from rural origins were particularly efficient in the development of urban trade activity. They could transfer some of their skills to the butchery, or bakery, or the restaurant trades, for example, while older craft activities were usually reserved for the indigenous population. ${ }^{29}$ In between the old and new middle classes, such active migrants benefited from urban dynamism and the development of an urban way of life, under the influence of bourgeois culture. $^{30}$

To that we must add that the relationship between migration and marital mobility is extremely complicated. As a result of the segmentation of the marriage market according to geographical origin, the characteristics of the migrant marriage market are crucial in explaining partnerselection patterns. We shall control for that in our empirical analysis. ${ }^{31}$

\section{Marriage}

Finally, there are matters more closely related to marriage practices that might be important. First, one wonders whether age at marriage matters. Lower-class children who married late had more chance of building up savings or investing in their careers. At a later age, it might also be clearer whether a newly achieved social position would be stable or not. ${ }^{32}$ In any case, the older one was, the more important was one's own social position rather than that of one's parents. Consequently, lower-class children who married quite late had more chance of attracting a middleclass spouse.

Second, whether someone was marrying for the first time or not surely played its part. First marriages have a strong symbolic value, and have always attracted greater community attention. ${ }^{33}$ Social closure might be particularly important for such occasions. ${ }^{34}$ Second unions are of course related to the question of age at marriage, and the impact of age on marital mobility. We must bear in mind that all these marriage-related 
characteristics are important as control variables, but they are not inherently connected to the hypotheses discussed above.

\subsection{Hypotheses and empirical claims}

We end this section by formulating some empirical claims based on our discussion above. Let us first discuss absolute mobility. According to the proletarianization and agricultural decline hypotheses, the chance of a person from a lower-class background marrying a middle-class (or elite) partner would decline with the declining size of the middle class. If, by contrast, we observe an increase in the size of the new middle class, and in the chances for persons from the lower classes of marrying upwardly, that would confirm the 'new middle class' hypothesis.

Next, we turn to relative marital mobility, distinguishing three hypotheses about its evolution. First, there is the classic meritocracy hypothesis. Second, there is the hypothesis that states that increased intermarriage is not the consequence of meritocracy, but of the decline of the old middle class (proletarianization, agricultural decline). Third, there is the social closure hypothesis, which denies an increase in societal openness in times of economic modernization. These three hypotheses lead to divergent empirical claims in terms of the evolution of the marital mobility pattern. If relative upward mobility increased for the lower classes, that confirms the meritocracy hypothesis, the proletarianization hypothesis, or the agricultural decline hypothesis. If not, it confirms the social closure hypothesis. The hypotheses also imply divergent expectations in terms of where evolutions can be expected. If upward marital mobility was most easily attained in cities with a modern economy and strong administrative functions, that would support the meritocracy hypothesis. If lower-class children were less likely to marry upwardly in purely industrial cities, that would support the social closure hypothesis.

We shall perform a more detailed analysis focusing on a series of variables that might, or might not, have enhanced marriage chances, as an extra test which will give us more information on the validity of the different hypotheses. First, it is important to know what section of the middle class was the most likely to accept (or to have to accept) intermarriage with the lower class. If it was the children of the petty bourgeoisie, that would confirm the proletarianization hypothesis. If the children of farmers were the ones most likely to intermarry with the lower class, that would confirm the agricultural decline hypothesis. If the children of the new middle class were the most likely, that would support the meritocracy hypothesis. 
Second, it is important to know which characteristics of a lower-class background enhanced the chances of upward marriage. If rural migrants had less chance of intermarrying, that would support the social closure hypothesis. Furthermore, if individuals from lower-class backgrounds but who were literate and had experienced upward intergenerational mobility had a similar chance of marrying middle-class or elite partners as middleclass individuals did, that would support the meritocracy hypothesis. If not, it would support the social closure hypothesis.

\section{DATA AND CONTEXT}

\subsection{Marriage certificates}

We have used marriage certificates from civil registration registers which are available for the entire nineteenth century. The certificates contain information about the actual marriages, some demographic history of the spouses and their parents, their occupations, ${ }^{35}$ their places of residence, and so on. For this study, we made use of several datasets which were constructed during previous research. Different sampling strategies were used: for Ghent, one in twelve marriage certificates was included, and for Liège one in ten; for Verviers an alphabetical sample was extracted based on the letter B, while for Leuven and Aalst we abstracted one in three marriage certificates. We have 8,575 marriage certificates for Ghent, 9,330 for Leuven, 5,496 for Aalst, 5,511 for Liège, and 3,459 for Verviers. The database contains information for the period 1800-1913, though for the Walloon cities of Liège and Verviers it ends at 1890.

\subsection{Context description}

Ghent and Liège are the biggest cities in the sample, with 160,000 and 148,000 inhabitants respectively in 1900 . The other cities were considerably smaller. Verviers numbered 49,000 inhabitants in 1900, Leuven 42,000, and Aalst 29,000.

In the nineteenth century Belgium pioneered industrial revolution on the European continent, but in a highly polarized way. For the cotton and woollen textile industry, Ghent and Verviers were most advanced in terms of mechanization and workforce from the end of the eighteenth century onwards. Ghent was a historic city. Its economy was based mainly on cotton, though other branches of the textile sector and engineering were important too. In the first half of the nineteenth century its population doubled and migration increased, and with that came a lower standard of living. ${ }^{36}$ In the second half of the nineteenth century population growth 
slowed. Unlike Ghent, Verviers was a small centre which underwent a phase of urban crisis similar to Ghent's in the first half of the nineteenth century. ${ }^{37}$ An agglomeration grew progressively along the river Vesdre.

The textile city of Aalst participated in a second wave of industrialization. In the first half of the nineteenth century it was a quiet, almost medieval city, where before 1880-1890 factories were still small with fewer than 100 workers. But from about that time industry expanded, factories became larger, and newly established manufacturers appeared who had to compete with already well-established firms in the big cities, so they exploited their labour forces intensively, imposing working conditions even worse than elsewhere. ${ }^{38}$

During the 1820 s, mechanization in the textile industry prompted the modernization of the iron industry, with its coke-fired blast furnaces, and of coal-mining in the area around Liège. Liège itself was a large city, like Ghent, with many professional men and shopkeepers working alongside both traditional artisans, such as weapon-makers, and newer types of workers including coal-miners. ${ }^{39}$ Liège was an old town right in the centre of a coal basin and attracted around itself a more or less coherent industrial agglomeration. ${ }^{40}$

Leuven was originally a medium-sized town with no very strong industrialization in the nineteenth century, although it lost the traditional craft and agricultural roots of its economy. ${ }^{41}$ Its transformation was very gradual and did not lead to many large-scale business enterprises or factories; rather Leuven played an important part in administration and education.

\section{METHOD}

\subsection{Variables}

Occupational information is the only information we have to measure class, and the occupations in the databases were coded using the HISCO scheme ${ }^{42}$ The next step was to combine HISCO codes into classes, using a class scheme, for which purpose we used the SOCPO scheme. ${ }^{43}$ The SOCPO scheme is composed of five social power levels, labelled 'elite', 'middle class', 'skilled workers', 'semi-skilled workers', and 'unskilled workers'. Occupations are coded as middle class if they refer to one of the following categories: medium-scale proprietors, typically master artisans, merchants, shopkeepers (the petty bourgeoisie), and farmers; non-manual skilled workers, such as clerks; and lower management, or 'medium commanders'. The class consists of both the old and new middle classes. ${ }^{44}$

Occupational information is not, of course, without problems. Occupational titles might for example refer to different types of work in 
different contexts. To cope with that problem, we proceeded cautiously. First, the SOCPO scheme is an explicit one based on a clear theory and a detailed coding procedure. Second, it has been empirically validated. The five social power levels differ clearly in terms of indicators of standard of living such as literacy, height, and wages. ${ }^{45}$ Finally, we admit that grouping all 'farmers' into a single class is a simplification. One must, however, bear in mind that the data analysed are urban areas with few farmers. ${ }^{46}$

\subsection{Analysis}

In this analysis, we take the perspective of grooms from a lower-class background and measure their chances of marrying a middle-class or elite bride. That requires some explanation.

First, in line with the theoretical section, we focused our analysis on the social origin of bride and groom by reference to the social position of their fathers. Second, we considered the chances of marrying a middle-class or elite bride, since one of our principal aims is to evaluate the impact of upward intergenerational mobility on marital mobility. We have no means of measuring female class positions satisfactorily because there are so many cases where information on the occupation of the bride is vague or non-existent. We do not of course think the question is inherently uninteresting, but for the moment its analysis is not feasible. Third, even though we are interested in the chances for the lower classes of marrying upwardly, in the theoretical section we focused primarily on evaluating the chances of marrying a middle-class partner. Obviously, for the lower classes there was a greater likelihood of marrying a middle-class than an elite partner, but having chosen upward marriage as the dependent variable we are theoretically interested in any upward marriage. We did not want to run into the difficulties of splitting the sample into the chances of marrying an elite bride rather than a middle-class one. We consider a marriage with either as upward marital mobility.

To organize the empirical research we distinguished five steps. Step 1 was a descriptive analysis of social structure and absolute marital mobility. We focused on the size of the middle class and its composition, measured by classifying the HISCO codes defined as 'middle class' into three groups: the new middle class (clerical workers, scientists, managers, and so on), the petty bourgeoisie (merchants, self-employed artisans), and farmers. That step allowed us to examine the impact of economic modernization by relating the changes in social structure to absolute marital mobility rates.

As step 2 we examined the evolution of relative marital mobility during the nineteenth century and the differences among the cities in our 
database. For these purposes, we performed a simple logistic regression analysis to examine our main question, namely whether the chance of marrying a middle-class or elite bride differed according to the social origin of the groom, and whether that difference changed over time.

We developed a series of models to execute step 2. Model 1A is the basic model and contains period, city, and the social origin of the groom as independent variables. In model $1 \mathrm{~B}$ we added group size ${ }^{47}$ to measure relative mobility chances. To measure chances over time and among cities we added interaction terms between both variables and the social origin of the groom in, respectively, models $1 \mathrm{C}$ and 1D. To control for the effect of the segmentation of the marriage market by geographical origin, we ran variant models that included a 'homogamy according to geographical origin' variable (models $2 \mathrm{~A}-\mathrm{D}$ ). Couples were categorized into this variable by taking into account the geographical origin of both groom and bride. The variable has the following categories: "native groom and native bride', 'native groom and rural migrant bride', 'native groom and urban migrant bride', 'rural migrant groom and native bride', 'rural migrant groom and rural migrant bride', 'rural migrant groom and urban migrant bride', 'urban migrant groom and native bride', 'urban migrant groom and rural migrant bride', and 'urban migrant groom and urban migrant bride'.

While in steps 1 and 2 we examined the general patterns in absolute and relative marital mobility, the further steps focus on a more detailed analysis of who married whom, which will enable us to shed more light on the variant claims (meritocracy, proletarianization, agricultural decline, social closure).

In step 3 we examined the inflow of lower-class sons into different middle-class categories (new middle class, petty bourgeoisie, and farmers) in every city.

In step 4 we examined what factors help to explain why some lowerclass sons succeeded in marrying upwardly. We used model 3, containing period, city, social origin of groom, and homogamy according to geographical origin as the standard independent variables, and added the literacy of the groom, the social position of the groom, and his age at marriage $(<24,>24$ and $<28,>28)$ and his matrimonial status (whether it was his first marriage or not) as new independent variables. ${ }^{48}$ To avoid numerous interaction terms, we limited step 4 to grooms of lower-class background.

In step 5 we evaluated the chances of someone from the "best part of the lower classes' marrying a middle-class or elite bride. If individuals belonging to even that category had less chance than those from the middle class itself of marrying a middle-class or elite bride, that would confirm 
the social closure hypothesis. For that step we used model 4, which includes period, city, group size, and homogamy according to geographical origin, but added a new variable to distinguish between the 'best part' of the lower class and the rest of them, based on the results of step 4. (By the 'best part' of the lower class we refer to those who had the characteristics that gave them the best chances of marrying upwardly.) The variable combines information on the social origin, social position, age, and literacy of the groom. ${ }^{49}$

\section{RESULTS}

\subsection{The social structure and absolute marital mobility}

Table 1 shows the evolution of the size of the middle class in each city. In the biggest cities, Ghent and Liège, and in Verviers the middle class did not increase during the nineteenth century. In those early industrializing cities, any increase in the size of the middle class was, apparently, compensated for by an increase in the size of the lower classes. In late-industrializing Aalst and non-industrial Leuven the relative size of the middle class decreased sharply.

Next we turn to the composition of the middle class (data not shown). In Ghent, the new middle class was relatively large, but it barely increased over time. After 1890 about 7.5 per cent of fathers of brides were part of the 'new' middle class, who accounted for about 30 per cent of the total middle class. In Liège the proportion of the new middle class was somewhat lower in the first half of the nineteenth century, with 4.1 per cent of all brides' fathers belonging to the new middle class, but later, between 1874 and 1890, that figure increased to about 7.5 per cent. For Aalst, Leuven, and Verviers, the new middle class was smaller compared with Ghent and Liège. The percentage of fathers of brides belonging to the new middle class was never larger than 4.5 per cent. At the same time, we observed a decline of the old middle class in Aalst, Leuven, Verviers, and Liège. For the petty bourgeoisie the most dramatic evolution was in Leuven, with a decrease of 11 percentage points, while for Ghent the proportion remained stable at about 8.4 per cent. The same pattern is visible for farmers, for whom the decline was most dramatic in Aalst and Leuven, where there was a decrease of about 11 percentage points.

To conclude, we can state firmly that in none of these cities did economic changes lead to a sufficient increase in the numbers of the new middle class to bring about any major structural changes to the marriage market.

In Table 2 we present the percentages of grooms with a specific social origin who succeeded in marrying a middle-class or elite bride. These 


\section{TABLE 1}

The evolution of the social structure, measured by the distribution of the social position of the fathers of brides (row \%), in Aalst, Ghent, Leuven, Liège and Verviers (1800-1913)

\begin{tabular}{|c|c|c|c|c|c|}
\hline & Elite & Middle-class & Skilled & Semi-skilled & Unskilled \\
\hline & & & AALST & & \\
\hline $1800-1850$ & 5 & 43.2 & 19.6 & 13.2 & 18.9 \\
\hline $1851-1873$ & 3.3 & 29.7 & 25 & 13.6 & 28.5 \\
\hline $1874-1890$ & 4.3 & 28.8 & 17.2 & 14.2 & 35.6 \\
\hline 1891-1913 & 4.4 & 24.8 & 23.7 & 26.7 & 20.4 \\
\hline \multirow[t]{2}{*}{$\mathrm{N}$} & 106 & 751 & 535 & 466 & 599 \\
\hline & & & GHENT & & \\
\hline $1800-1850$ & 7.7 & 24.2 & 31.7 & 19.9 & 16.5 \\
\hline $1851-1873$ & 6.5 & 25.9 & 32.3 & 13.2 & 22.1 \\
\hline $1874-1890$ & 5.4 & 27.5 & 31.3 & 14.4 & 21.5 \\
\hline 1891-1913 & 6.6 & 24.8 & 30.1 & 20 & 18.5 \\
\hline \multirow[t]{2}{*}{$\mathrm{N}$} & 247 & 946 & 1162 & 656 & 718 \\
\hline & & & LEUVEN & & \\
\hline $1800-1850$ & 9.5 & 45.6 & 14.3 & 16.6 & 13.9 \\
\hline $1851-1873$ & 6.7 & 38.2 & 18.6 & 19.4 & 17 \\
\hline $1874-1890$ & 11 & 26.6 & 18.6 & 25.6 & 18.2 \\
\hline $1891-1913$ & 9.9 & 23.8 & 38.5 & 13.1 & 14.8 \\
\hline \multirow[t]{2}{*}{$\mathrm{N}$} & 372 & 1329 & 952 & 697 & 617 \\
\hline & & & VERVIERS & & \\
\hline $1800-1850$ & 4.1 & 32.9 & 17.3 & 30.2 & 15.6 \\
\hline $1851-1873$ & 3.8 & 28.4 & 21 & 31.7 & 15.1 \\
\hline $1874-1890$ & 7.5 & 28.1 & 25.8 & 24.7 & 13.9 \\
\hline \multirow[t]{2}{*}{$\mathrm{N}$} & 80 & 454 & 342 & 452 & 230 \\
\hline & & & LIEGE & & \\
\hline $1800-1850$ & 8.3 & 23.1 & 24.9 & 25.6 & 18.1 \\
\hline $1851-1873$ & 11 & 18.4 & 28 & 17.5 & 25.2 \\
\hline $1874-1890$ & 10.1 & 23.2 & 32.4 & 16.5 & 17.9 \\
\hline $\mathrm{N}$ & 231 & 477 & 661 & 420 & 478 \\
\hline
\end{tabular}

Source: Samples of marriage certificates in civil registration registers of the cities of Aalst, Ghent, Leuven, Verviers and Liège.

figures reflect the evolution of the social structure. For Leuven and Aalst, two cities that experienced a sharp decline of the middle class, the chances for a groom with a lower-class background of marrying upwardly decreased dramatically. While in the first half of the nineteenth century the chance of marrying upwardly was relatively large (between 35 and 27 per cent in Leuven; between 45 and 32 per cent in Aalst), it declined to less than 20 per cent. In the other cities there was hardly any evolution. These 


\section{TABLE 2}

Chances, by social origin, of marrying a middle-class or elite bride (\%) in Aalst, Ghent, Leuven, Liège and Verviers (1800-1913)

\begin{tabular}{|c|c|c|c|c|c|}
\hline & Elite & Middle-class & Skilled & Semi-skilled & Unskilled \\
\hline & & & AALST & & \\
\hline $1800-1850$ & 58.3 & 52.9 & 44.9 & 35.7 & 31.6 \\
\hline $1851-1873$ & 87.5 & 53.8 & 25.4 & 16.7 & 12.9 \\
\hline $1874-1890$ & 84.6 & 42 & 19.1 & 10.3 & 11.2 \\
\hline 1891-1913 & 50 & 43.3 & 15.3 & 18.2 & 17.4 \\
\hline \multirow[t]{2}{*}{$\mathrm{N}$} & 63 & 395 & 299 & 267 & 322 \\
\hline & & & GHENT & & \\
\hline $1800-1850$ & 86.8 & 47.2 & 22.8 & 19.5 & 5.6 \\
\hline $1851-1873$ & 79.3 & 48.8 & 20.2 & 9.5 & 12.7 \\
\hline 1874-1890 & 85.7 & 44 & 24.6 & 24.5 & 15.8 \\
\hline 1891-1913 & 68.1 & 49.2 & 21.5 & 19.7 & 16.8 \\
\hline \multirow[t]{2}{*}{$\mathrm{N}$} & 128 & 468 & 633 & 325 & 382 \\
\hline & & & LEUVEN & & \\
\hline $1800-1850$ & 76.1 & 57.9 & 34.6 & 30.5 & 27.1 \\
\hline $1851-1873$ & 87.5 & 57.9 & 30.3 & 17.8 & 15.7 \\
\hline $1874-1890$ & 77.1 & 41 & 35.4 & 8 & 13.2 \\
\hline 1891-1913 & 75.9 & 36.9 & 18.8 & 18.7 & 13.3 \\
\hline \multirow[t]{2}{*}{$\mathrm{N}$} & 188 & 656 & 526 & 349 & 309 \\
\hline & & & VERVIERS & & \\
\hline $1800-1850$ & 80 & 48.2 & 51.9 & 22.7 & 23.5 \\
\hline $1851-1873$ & 84.2 & 34.1 & 22.7 & 17.5 & 25.4 \\
\hline $1874-1890$ & 64 & 46.8 & 23.4 & 19.7 & 12.1 \\
\hline \multirow[t]{2}{*}{$\mathrm{N}$} & 54 & 259 & 192 & 258 & 117 \\
\hline & & & LIEGE & & \\
\hline $1800-1850$ & 71.4 & 55.4 & 25 & 20 & 11.5 \\
\hline $1851-1873$ & 55.7 & 45.4 & 23.6 & 17 & 16.3 \\
\hline $1874-1890$ & 59.6 & 40.4 & 25.6 & 21.4 & 21.2 \\
\hline $\mathrm{N}$ & 123 & 252 & 321 & 213 & 253 \\
\hline
\end{tabular}

Source: Samples of marriage certificates in civil registration registers of the cities of Aalst, Ghent, Leuven, Verviers and Liège.

results do not leave much doubt. Economic modernization did not lead to increased absolute chances of marrying upwardly for lower-class sons.

\subsection{Relative marital mobility}

Table 3 shows the results of the logistic regression analysis. The chance of marrying a middle-class or elite bride was clearly lower after the first half of the nineteenth century (model 1A). Note that such is the logical 
TABLE 3

Logistic regression analysis of the chances of marrying a middle-class or elite bride in Aalst, Ghent, Leuven, Liège and Verviers (1800-1913) (models $1 A-D, 2 A-D)$

\begin{tabular}{|c|c|c|c|c|c|c|c|c|}
\hline & Model $1 A$ & Model $1 B$ & Model 1C & Model $1 D$ & Model $2 A$ & Model $2 B$ & Model 2C & Model 2D \\
\hline \multicolumn{9}{|l|}{ Period } \\
\hline \multicolumn{9}{|l|}{$1800-1850$} \\
\hline $1851-1873$ & $0.754 * * *$ & 0.998 & 1.104 & 1.026 & $0.720 * * *$ & 0.925 & 0.984 & 0.946 \\
\hline $1874-1890$ & $0.700 * * *$ & 1.012 & 1.011 & 1.039 & $0.679 * * *$ & 0.943 & 0.886 & 0.962 \\
\hline $1891-1913$ & $0.629 * * *$ & 1.019 & 1.111 & 1.042 & $0.594 * * *$ & 0.916 & 0.950 & 0.936 \\
\hline \multicolumn{9}{|l|}{ Social origin groom } \\
\hline \multicolumn{9}{|l|}{ Middle-class } \\
\hline Elite & $2.956^{* * *}$ & $3.022 * * *$ & $3.245 * * *$ & $2.050 * *$ & $3.147 * * *$ & $3.194 * * *$ & $3.139 * * *$ & $1.772^{*}$ \\
\hline Skilled & $0.371 * * *$ & $0.380 * * *$ & $0.441 * * *$ & $0.338 * * *$ & $0.412 * * *$ & $0.420 * * *$ & $0.459 * * *$ & $0.345^{* * *}$ \\
\hline Semi-skilled & $0.271^{* * *}$ & $0.275^{* * *}$ & $0.310 * * *$ & $0.281 * * *$ & $0.293 * * *$ & $0.296^{* * *}$ & $0.321 * * *$ & $0.285^{* * *}$ \\
\hline Unskilled & $0.225 * * *$ & $0.230 * * *$ & $0.207 * * *$ & $0.230 * * *$ & $0.230 * * *$ & $0.234 * * *$ & $0.203 * * *$ & $0.236^{* * *}$ \\
\hline \multicolumn{9}{|l|}{ City } \\
\hline \multicolumn{9}{|l|}{ Aalst } \\
\hline Ghent & 0.98 & 0.981 & 0.980 & 1.03 & $0.856^{*}$ & $0.858^{*}$ & $0.856^{*}$ & 0.860 \\
\hline Leuven & 1.083 & 0.87 & 0.889 & $0.792^{*}$ & 0.942 & $0.775^{* *}$ & $0.793 * *$ & $0.669 * *$ \\
\hline Verviers & 0.953 & 1.049 & 1.063 & 0.811 & $0.688^{* *}$ & $0.752^{* *}$ & $0.759 * *$ & $0.568^{* *}$ \\
\hline Liège & 0.894 & 0.909 & 0.911 & 0.916 & $0.670 * * *$ & $0.683^{* * *}$ & $0.681 * * *$ & $0.675^{* *}$ \\
\hline \multicolumn{9}{|l|}{ Geographical homogamy } \\
\hline \multicolumn{9}{|l|}{ Groom and bride are natives } \\
\hline Groom is native, bride is rural migrant & & & & & $2.362^{* * *}$ & $2.340 * * *$ & $0.479 * * *$ & $2.362 * * *$ \\
\hline Groom is native, bride is urban migrant & & & & & $1.410 * *$ & $1.397 * *$ & 1.119 & $1.406^{* *}$ \\
\hline Groom is rural migrant, bride is native & & & & & 1.289 & $1.291 * *$ & $0.669 * *$ & $1.282 * *$ \\
\hline Groom and bride are rural migrants & & & & & 2.595 & $2.523 * * *$ & $0.614 * * *$ & $2.620 * * *$ \\
\hline
\end{tabular}


TABLe 3 (Cont.)

\begin{tabular}{|c|c|c|c|c|c|c|c|c|}
\hline & Model $1 A$ & Model $1 B$ & Model $1 C$ & Model $1 D$ & Model $2 A$ & Model $2 B$ & Model $2 C$ & Model 2D \\
\hline $\begin{array}{l}\text { Groom is rural migrant, bride is } \\
\text { urban migrant }\end{array}$ & & & & & 1.647 & $1.639 * *$ & 1.214 & $1.638 * *$ \\
\hline Groom is urban migrant, bride is native & & & & & 1.601 & $1.615 * * *$ & 0.788 & $1.592 * * *$ \\
\hline $\begin{array}{l}\text { Groom is urban migrant, bride is } \\
\text { rural migrant }\end{array}$ & & & & & 2.580 & $2.590 * * *$ & $0.770 * *$ & $2.566^{* * *}$ \\
\hline Groom and bride are urban migrants & & & & & 2.079 & $2.081 * * *$ & 1.241 & $2.045^{* * *}$ \\
\hline Group size & & $1.041 * * *$ & $1.041^{* * *}$ & $1.044 * * *$ & & $1.037 * * *$ & $1.036^{* * *}$ & $1.040 * * *$ \\
\hline \multicolumn{9}{|l|}{ Period $*$ Social origin } \\
\hline $1851-1873 *$ elite & & & 0.894 & & & & 1.065 & \\
\hline $1851-1873 *$ skilled & & & 0.809 & & & & 0.852 & \\
\hline $1851-1873 *$ semi-skilled & & & 0.723 & & & & 0.743 & \\
\hline $1851-1873 *$ unskilled & & & 1.097 & & & & 1.136 & \\
\hline $1874-1890 *$ elite & & & 0.959 & & & & 1.106 & \\
\hline $1874-1890 *$ skilled & & & 1.043 & & & & 1.157 & \\
\hline $1874-1890 *$ semi-skilled & & & 0.844 & & & & 0.928 & \\
\hline $1874-1890 *$ unskilled & & & 1.130 & & & & 1.168 & \\
\hline $1891-1913 *$ elite & & & 0.885 & & & & 0.920 & \\
\hline $1891-1913 *$ skilled & & & $0.704 *$ & & & & 0.762 & \\
\hline $1891-1913 *$ semi-skilled & & & 0.978 & & & & 1.027 & \\
\hline 1891-1913* unskilled & & & 1.186 & & & & 1.289 & \\
\hline \multicolumn{9}{|l|}{ City $*$ social origin } \\
\hline Ghent $*$ elite & & & & $1.905^{*}$ & & & & $2.329 * *$ \\
\hline Ghent $*$ skilled & & & & 0.923 & & & & 1.032 \\
\hline Ghent $*$ semi-skilled & & & & 0.920 & & & & 0.990 \\
\hline Ghent $*$ unskilled & & & & 0.753 & & & & 0.744 \\
\hline Leuven $*$ elite & & & & $2.052 * *$ & & & & $2.431 * *$ \\
\hline
\end{tabular}




\begin{tabular}{|c|c|c|c|c|c|c|c|c|}
\hline Leuven $*$ skilled & & & & 1.221 & & & & 1.367 \\
\hline Leuven $*$ semi-skilled & & & & 0.886 & & & & 0.987 \\
\hline Leuven $*$ unskilled & & & & 0.986 & & & & 1.024 \\
\hline Verviers $*$ elite & & & & 2.049 & & & & $2.661^{* *}$ \\
\hline Verviers $*$ skilled & & & & $1.632^{*}$ & & & & $1.662^{*}$ \\
\hline Verviers $*$ semi-skilled & & & & 1.221 & & & & 1.299 \\
\hline Verviers $*$ unskilled & & & & $1.752^{*}$ & & & & $1.743^{*}$ \\
\hline Liège $*$ elite & & & & 0.815 & & & & 1.117 \\
\hline Liège $*$ skilled & & & & 1.166 & & & & 1.258 \\
\hline Liège $*$ semi-skilled & & & & 1.013 & & & & 1.024 \\
\hline Liège $*$ unskilled & & & & 1.037 & & & & 0.915 \\
\hline Constant & $1.157^{*}$ & $0.239^{* * *}$ & $0.227 * * *$ & $0.225^{* * *}$ & 0.945 & $0.229 * * *$ & $0.486^{* *}$ & $0.226^{* * *}$ \\
\hline $\mathrm{N}$ & 7352 & 7352 & 7352 & 7352 & 7230 & 7230 & 7230 & 7230 \\
\hline \multicolumn{9}{|c|}{$\begin{array}{l}\text { Significance } *<0.10 ; * *<0.05 \\
* * *<0.001\end{array}$} \\
\hline Nagelkerke $\mathrm{R}^{2}$ & 0.174 & 0.178 & 0.180 & 0.183 & 0.198 & 0.202 & 0.203 & 0.206 \\
\hline
\end{tabular}

Source: Samples of marriage certificates in civil registration registers of the cities of Aalst, Ghent, Leuven, Verviers and Liège. 


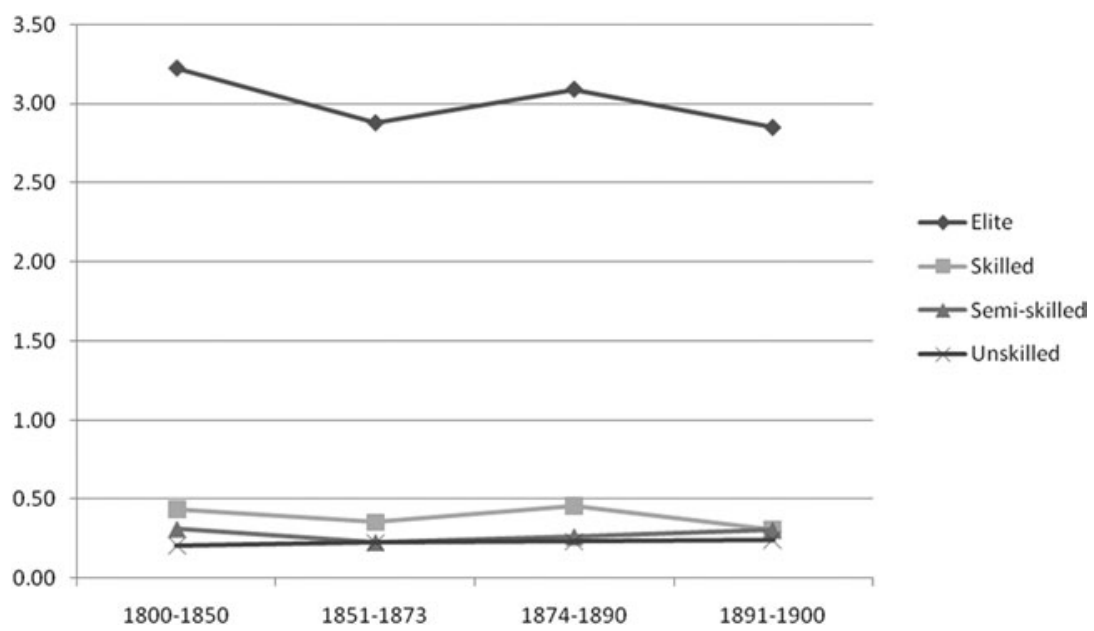

FIGURE 1. Evolution of the different chances by social origin of marrying a middle-class or elite bride in Aalst, Ghent, Leuven, Liège and Verviers (1800-1913) (model 1C). (Source: Samples of marriage certificates in civil registration registers of the cities of Aalst, Ghent, Leuven, Verviers and Liège.)

consequence of the decrease in the size of the middle class, which is shown by controlling for group size (model 1B). The results in model 1 show differences in grooms according to their social origin. The elite were more likely to marry a middle-class or elite bride compared with the middleclass. Grooms from a lower-class background were less likely. Those findings are, of course, as expected and not controversial.

More important is the question of how those differences by social origin evolved. Model 1C shows the results of a model that includes interaction terms for period and social origin, which then enables us to determine whether the different marriage chances changed over time. It is clear that they did not. Figure 1 shows the results, calculated so that the evolution of the different marriage chances of each type of groom are compared with the evolution of the chances of grooms from a middle-class background (set at 1 for the whole period).

There is no indication that lower-class sons found it easier to attract a middle-class or elite bride in the second half of the nineteenth century, which is the finding giving the most straightforward support to the claim that meritocracy was not strong enough to reshape partner-selection patterns so that it became easier for lower-class sons to marry upwardly. Nor did agricultural decline or proletarianization weaken the position of the old middle class enough to mean that they were increasingly obliged to accept intermarriage with the lower class. ${ }^{50}$ 


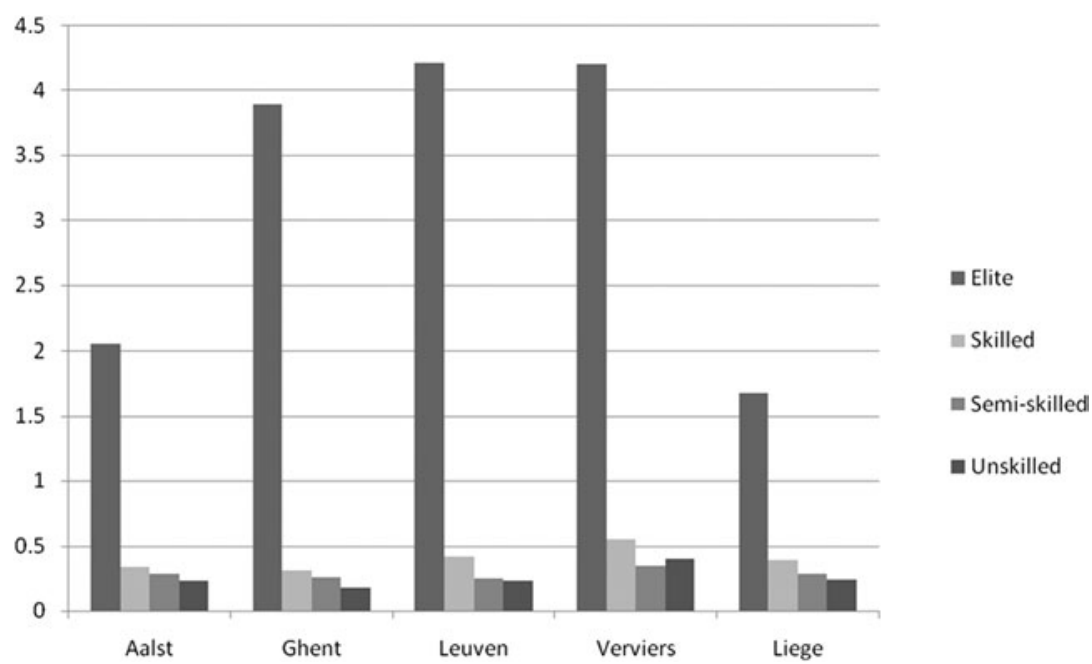

FIGURE 2. Different chances by social origin of marrying a middle-class or elite bride in Aalst, Ghent, Leuven, Liège and Verviers (1800-1913), differences between the cities (model 1D). (Source: Samples of marriage certificates in civil registration registers of the cities of Aalst, Ghent, Leuven, Verviers and Liège.)

In model $1 \mathrm{D}$ we added interaction terms for the location and social origin of the groom to model $1 \mathrm{~B}$. Figure 2 shows the patterns for the five cities, with the values for the middle class set at 1 for the whole period. The results indicate that there were few differences among the cities in terms of different marriage chances. The early-industrial cities of Ghent and Verviers (and Liège) do not differ systematically from Leuven or from late-industrial Aalst.

So, while the lack of a general increase in upward mobility is evidence against the meritocracy hypothesis, the lack of differences between industrial and non-industrial cities is not very supportive of the social closure hypothesis. On the other hand, it has been demonstrated before for the industrial cities of Ghent and Aalst after 1890 - and, using the same class scheme, for some districts in the United Kingdom ${ }^{51}$ - that the social closure strategy led to demographic class formation in such a way that intermarriage within the lower classes increased, while intermarriage with the middle class remained stable. In other words, social closure was not so strong that it dramatically reduced the likelihood of upward marriage, but that did not prevent the internal boundaries within the lower class from becoming more permeable in industrial cities.

This section ends with a short note on the influence of migration. As outlined in the theoretical section, segmentation of the marriage market 
might well have had an impact on partner-selection patterns. In models $2 \mathrm{~A}-\mathrm{D}$ we added homogamy according to geographical origin to model 1. The findings, presented in Table 3, show that there probably was segmentation. Grooms who married on the 'rural' marriage market (those grooms marrying rural migrants) had more chance of marrying upwardly, and that was related to the high proportion of children of farmers among those migrants. If one married a rural migrant, then one automatically had a greater chance of marrying a middle-class bride. Those who married on the non-rural market had somewhat less chance of doing so, while those marrying on the native marriage market were the least likely to do so.

However, it is important for our purposes that adding this migration variable should not alter the conclusions arrived at using model 1 above. It is apparent that possible changes in the segmentation of the marriage market or in the number of migrants were not strong enough to influence the parameters obtained by model 1 .

Much more can be said about migration and marital mobility, but that is beyond the scope of this article. But one interesting finding appears when we compare the results for each category in which the bride was a native. Rural migrants, and particularly urban migrants who did marry a native partner had more chance than native grooms of marrying upwardly, and we shall discuss that in somewhat more detail in section 4.4, below.

\subsection{Who married downwardly?}

In the next steps we shall examine in more detail who married whom in order to get more insight into the findings of the previous section. First we examine the marriage market from the perspective of the middle class (see Table 4). Which category of the middle class was most likely to accept a downward marriage? Note that for each of the subgroups of the middle class the structural chance of marrying a lower-class partner was the same. For this reason comparison of the percentages in Table 4 teaches us something about the differences in preferences for marrying a lower-class partner.

Daughters of farmers in the first half of the nineteenth century were not very likely to marry a groom from the lower class (about 50 to 65 per cent did not), but that percentage dropped in the late nineteenth century. The pattern for the petty bourgeoisie was somewhat different in each city. In Ghent, and particularly in Leuven, the daughters of the petty bourgeoisie increasingly had to accept downward marriage, while in Aalst and Liège there was no change and in Verviers there was a modest increase. Finally, 


\section{TABLE 4}

Percentages of brides from different middle-class subgroups who did not marry a groom with a lower-class background, in Aalst, Ghent, Leuven, Liège and Verviers (1800-1913) (row \%)

\begin{tabular}{|c|c|c|c|}
\hline $\begin{array}{l}\text { Social origin } \\
\text { of bride: }\end{array}$ & $\begin{array}{l}\text { New middle } \\
\text { class }\end{array}$ & Petty bourgeoisie & Farmers \\
\hline & \multicolumn{3}{|c|}{ AALST } \\
\hline $1800-1850$ & 27.3 & 40 & 65.4 \\
\hline $1851-1874$ & 28.6 & 47.1 & 65.8 \\
\hline $1875-1890$ & 40 & 50 & 64.9 \\
\hline $1891-1913$ & 60 & 46.2 & 47.8 \\
\hline \multirow[t]{2}{*}{$\mathrm{N}$} & 33 & 82 & 219 \\
\hline & \multicolumn{3}{|c|}{ GHENT } \\
\hline $1800-1850$ & 50 & 60.5 & 55.9 \\
\hline $1851-1874$ & 46.7 & 44.1 & 66.7 \\
\hline $1875-1890$ & 45.8 & 40 & 47.5 \\
\hline $1891-1913$ & 60 & 41.3 & 44.9 \\
\hline \multirow[t]{2}{*}{$\mathrm{N}$} & 116 & 177 & 173 \\
\hline & \multicolumn{3}{|c|}{ LEUVEN } \\
\hline $1800-1850$ & 68.4 & 72.3 & 65.9 \\
\hline $1851-1874$ & 40 & 65.8 & 68.3 \\
\hline $1875-1890$ & 46.7 & 46.7 & 73 \\
\hline $1891-1913$ & 56.7 & 33.3 & 47.8 \\
\hline \multirow[t]{2}{*}{$\mathrm{N}$} & 74 & 220 & 228 \\
\hline & \multicolumn{3}{|c|}{ VERVIERS } \\
\hline $1800-1850$ & 16.7 & 47.6 & 52.4 \\
\hline $1851-1874$ & 47.6 & 42.9 & 35.6 \\
\hline $1875-1890$ & 54.5 & 61.1 & 48.6 \\
\hline \multirow[t]{2}{*}{$\mathrm{N}$} & 38 & 53 & 115 \\
\hline & \multicolumn{3}{|c|}{ LIEGE } \\
\hline $1800-1850$ & 42.9 & 62.5 & 58.1 \\
\hline $1851-1874$ & 58.3 & 57.9 & 55.8 \\
\hline $1875-1890$ & 47.8 & 55.6 & 42.9 \\
\hline $\mathrm{N}$ & 66 & 63 & 102 \\
\hline
\end{tabular}

Source: Samples of marriage certificates in civil registration registers of the cities of Aalst, Ghent, Leuven, Verviers and Liège.

the pattern for the new middle class was somewhat clearer. In most cities, new middle class daughters did not show an increase in downward marital mobility.

As a result of such evolutions, in these Flemish cities in the final period of observation the new middle class was more able than the other components of the middle class to prevent downward mobility, although that was less evident in the Walloon cities of Verviers and Liège. In contrast, 


\section{TABLE 5}

Logistic regression analysis of the chances of marrying a middle-class or elite bride in Aalst, Ghent, Leuven, Liège and Verviers (1800-1913), model 3 (grooms with a lower-class background) and 4 (all grooms)

\begin{tabular}{|c|c|c|}
\hline & Model 3 & Model 4 \\
\hline \multicolumn{3}{|l|}{ Period } \\
\hline \multicolumn{3}{|l|}{$1800-1850$} \\
\hline $1851-1873$ & 0.829 & 0.952 \\
\hline $1874-1890$ & 0.886 & 0.985 \\
\hline $1891-1913$ & 0.878 & 0.989 \\
\hline \multicolumn{3}{|l|}{ Social origin groom } \\
\hline \multicolumn{3}{|l|}{ Skilled } \\
\hline Semi-skilled & 0.852 & \\
\hline Unskilled & $0.811^{*}$ & \\
\hline \multicolumn{3}{|l|}{ City } \\
\hline \multicolumn{3}{|l|}{ Aalst } \\
\hline Ghent & $0.672 * *$ & 0.895 \\
\hline Leuven & $0.570^{* * *}$ & $0.760^{*}$ \\
\hline Verviers & $0.573 * *$ & $0.772 * *$ \\
\hline Liège & $0.337 * * *$ & $0.663^{* * *}$ \\
\hline \multicolumn{3}{|l|}{ Social position groom } \\
\hline \multicolumn{3}{|l|}{ Middle-class } \\
\hline Elite & 1.570 & \\
\hline Skilled & $0.472 * * *$ & \\
\hline Semi-skilled & $0.350^{* * * *}$ & \\
\hline Unskilled & $0.287 * * *$ & \\
\hline \multicolumn{3}{|l|}{ Migrant status } \\
\hline \multicolumn{3}{|l|}{ Groom and bride are natives } \\
\hline Groom is native, bride is rural migrant & $3.184^{* * *}$ & $2.726 * * *$ \\
\hline Groom is native, bride is urban migrant & $1.527 * *$ & $1.454^{* *}$ \\
\hline Groom is rural migrant, bride is native & $1.518^{* *}$ & $1.306^{* *}$ \\
\hline Groom and bride are rural migrants & $3.403 * * *$ & $3.041^{* * *}$ \\
\hline Groom is rural migrant, bride is urban migrant & $1.682^{*}$ & $1.724^{* *}$ \\
\hline Groom is urban migrant, bride is native & $1.405^{* *}$ & $1.476^{* * *}$ \\
\hline Groom is urban migrant, bride is rural migrant & $3.689 * * *$ & $3.104 * * *$ \\
\hline Groom and bride are urban migrants & $1.856^{* *}$ & $2.133^{* * *}$ \\
\hline \multicolumn{3}{|l|}{ Illiteracy of groom } \\
\hline \multicolumn{3}{|l|}{ Can read and write } \\
\hline Cannot read and write & $0.496^{* * *}$ & \\
\hline \multicolumn{3}{|l|}{ Age of groom } \\
\hline \multicolumn{3}{|l|}{ Younger than 24} \\
\hline Between 25 and 28 & 1.136 & \\
\hline Older than 28 & $1.677 * * *$ & \\
\hline
\end{tabular}




\section{TABLE 5 (Cont.)}

\begin{tabular}{|c|c|c|}
\hline & Model 3 & Model 4 \\
\hline Brides group size & $1.058 * * *$ & $1.044 * * *$ \\
\hline \multicolumn{3}{|l|}{ Matrimonial status of groom } \\
\hline Married before & 1.231 & $1.413 * *$ \\
\hline \multicolumn{3}{|l|}{ Social origin + social position groom } \\
\hline Father middle-class and groom lower-class & & $0.327 * * *$ \\
\hline Father elite and groom lower-class & & $0.481 * *$ \\
\hline Father elite and groom middle-class or elite & & $2.560 * * *$ \\
\hline $\begin{array}{l}\text { Father lower-class and groom middle-class or } \\
\text { elite, literate and older than } 28\end{array}$ & & $0.601^{* *}$ \\
\hline $\begin{array}{l}\text { Father lower-class and groom lower-class } \\
\text { or not in previous category }\end{array}$ & & $0.150^{* * *}$ \\
\hline Constant & $0.127^{* * *}$ & $0.312 * *$ \\
\hline $\mathrm{N}$ & 4068 & 6659 \\
\hline \multicolumn{3}{|l|}{ Significance $*<0.10 ; * *<0.05 ; * * *<0.001$} \\
\hline Nagelkerke $\mathrm{R}^{2}$ & 0.143 & 0.253 \\
\hline
\end{tabular}

Source: Samples of marriage certificates in civil registration registers of the cities of Aalst, Ghent, Leuven, Verviers and Liège.

the new middle class was the component least able to prevent downward marital mobility during the first half of the nineteenth century, in both the Flemish and Walloon cities.

In our view, that finding brings some nuance to the conclusion of the previous section. Even though, in general, there was no increase in relative upward mobility for lower-class sons, in this section, based on more specific information taking into account the different positions of the different subgroups of the middle class, the figures support the view that proletarianization of the middle class, in some cities, and agricultural decline in almost every city, diminished the social distance between the 'old' middle class and the lower class. And apparently, the meritocratization of the new middle class did not result in increased intermarriage with the lower classes, in fact quite the contrary. But those changes were not strong enough to affect the general pattern.

\subsection{Who married upwardly?}

In this section we limit our analysis to lower-class grooms. In model 3 (see Table 5) we included variables that we thought could be related to an 
upward marriage, such as social origin, social position, literacy, age at marriage, and matrimonial status. Sons of skilled workers had more chances of marrying upwardly, yet controlling for all these independent variables made the direct effect of social origin insignificant at the 0.05 significance level. The groom's own social position was important and significant. Those who themselves remained in the lower classes had lower chances of marrying upwardly, but the difference between sons who attained an elite position and those who attained a middle-class position was not significant. ${ }^{\mathbf{5}}$ Literacy too was important. Grooms who were unable to sign their marriage certificate had half the chances of upward marriage of those who could. Both variables show that achievement did play a role, in the sense that upward intergenerational mobility and participation in literate culture could be translated into upward marital mobility.

Perhaps related to that is the influence of age at marriage. The chance of marrying a middle-class or elite bride was 1.7 times greater for sons who married after their twenty-eighth birthday compared with sons who married by the time they were 24 . While we expected a positive effect from age at marriage, we were somewhat surprised by its magnitude. Apparently, lower-class grooms who could save, or perhaps establish a solid career, were better able to attract a middle-class or elite bride. There is no effect from remarriage, but the number of remarrying grooms for whom we have information on the father's occupation is very limited (136 observations for the whole sample in Table 4).

For the lower classes we find that rural migrants and non-rural migrants who married a native partner had more chance than native grooms of marrying a middle-class or elite bride. That is a puzzling finding. Rural migrants were not the ones most likely to be part of the core of the city population and they even tended to be particularly unpopular. ${ }^{53}$ From a social closure perspective, they were the ones one might have expected to be least likely to contract an upward marriage. On the other hand, the finding is consistent with the dynamic economic activities of rural migrants in the food sector, as described in the theoretical section, above.

Perhaps it is more illuminating to look at the results from the perspective of the native working class. One cannot exclude the possibility that they were more reluctant to intermingle with the middle class and the elite, and perhaps the high level of social cohesion among them contributed to that. In other words, social origin was not necessarily as important socially for migrants as for non-migrants, which conforms to Sewell's interpretation of the lack of social mobility of the native working class in nineteenth-century Marseille, which he attributes to their adherence to their working-class identity. ${ }^{54}$ 


\subsection{Meritocracy or social closure?}

From the previous section we learned that grooms from a lower-class background who succeeded in achieving a higher social position for themselves, who were literate, or who married rather later had more chance of attracting a middle-class or elite bride. A crucial test is whether grooms who combined all those characteristics had as much chance as grooms already from a middle-class background of marrying upwardly. If so, that would mean there was at least some meritocracy, that is, that the few who really succeeded in achieving a good position did not encounter many problems in entering higher social circles.

Thus in the next analysis we examine whether 'the best of the lower class' were able to attract a middle-class or elite bride. In Table 5 (model 4) we compare the chances of marrying a middle-class or elite bride for elite, middle-class, and lower-class sons. In the latter category, we distinguish those sons who improved their situation by upward intergenerational mobility (middle-class or elite position) and by literacy, and who had waited long enough to marry.

The results show that they did indeed have more chance than other lower-class sons of marrying upwardly, yet they still had significantly less chance of doing so than middle-class sons had of marrying a middle-class or elite bride. Even that upper level of the lower-class group could not 'make it' on the basis of their own achievements. In our interpretation, that provides yet more support for the social closure hypothesis.

We should bear in mind, however, that middle-class sons who were not able to maintain their position had less chance of marrying a middle-class or elite bride than sons who can be defined as the 'best part of the lower class'. If we use the latter group as the reference category, the parameter was $0.523(\mathrm{p}=0.005)$ for middle-class sons who did not maintain their position. However, we must not over-interpret that finding. Our 'best part of the lower class' contained about 2 per cent of the whole lower-class group. Given its tiny size, there is little to be gained from exploring this group further, for example according to time and place.

\section{CONCLUSION}

In the theoretical section we stated that the main test of the relationship between economic modernization and societal openness concerned the evolution during the nineteenth century of the chances for individuals from a lower-class background of experiencing upward marital mobility. In terms of absolute mobility, we found that in the non-industrial city of Leuven and the late-industrial city of Aalst, the decline of the old middle 
class led to a decreasing chance for the lower classes of marrying upwardly. For those cities, the proletarianization and agricultural decline hypotheses for absolute marital mobility are supported. For the other cities, there was no such effect, but neither was there support for the view that the rise of the new middle class reshaped marriage patterns. In short, for the lower classes economic modernization did not have positive effects on absolute upward marital mobility. At best, their chances of marrying a middle-class or elite partner did not decrease.

The conclusion in terms of relative marital mobility is also clear. The chances of marrying upwardly remained stable, and that is evidence against the meritocracy hypothesis, which claims that economic modernization gradually led to increased societal openness, and also against the proletarianization and the agricultural decline hypotheses, which claim that due to those processes the old middle class, while formally keeping its middle-class occupational titles, became 'informally' devalued and had to accept intermarriage with the lower classes. However, note, as explained above, that the latter transitions did reshape the social structure. Apparently, social closure was strong enough to counter any trend towards upward marital mobility.

Some further findings corroborate our conclusions. First, as particularly the new middle class showed no sign of increased intermarriage with the lower class, that is evidence against the meritocracy hypothesis. Second, as personal characteristics such as literacy and intergenerational mobility did not lead to a complete acceptance within the middle class or the elite, that too is not supportive of the meritocracy hypothesis.

The social closure hypothesis was the one most strongly supported. However, that does not mean that all our evidence is in favour of it. First, rural migrants did not have less chance of marrying a middle-class or elite bride, which one might otherwise have expected in cases where social closure principles determined partner selection. Second, there is no sign that the lower classes had less chance of marrying a middle-class partner in industrial cities, which, again, would have been likely from the social closure perspective. Altogether, we do not think those observations are crucial. In our opinion, in the nineteenth century strategies of social closure, even in industrial cities, remained strong enough to prevent an increase of intermarriage between lower-class grooms and middle-class or elite brides. ${ }^{55}$

The present study does of course have its limits. For example, the analyses presented above examine partner selection only from the perspective of the lower-class groom. It is an open question whether the same results would be found if we took the perspective of lower-class women. 
Finally, as a general conclusion, it is important to state that our results are based on a database derived from the most modern economies of Belgium, and therefore of continental Europe at the time. As there is no support found in it for the meritocracy hypothesis, that implies that it is not very likely that meritocracy strongly affected marital mobility anywhere in the nineteenth century, unless there were other conditions, not strictly related to economic modernization, that stimulated meritocracy.

\section{ACKNOWLEDGEMENTS}

The authors would like to thank Svetlana Jidkova for her support in database management and statistical analysis.

\section{ENDNOTES}

1 B. Van de Putte, Partnerkeuze in de 19de eeuw: klasse, geografische afkomst, romantiek en de vorming van sociale groepen op de huwelijksmarkt (Leuven, 2005).

2 S. Beauvalet-Boutouyrie, La démographie de l'époque moderne (Paris, 1999), 125.

3 See, for example, R. Erikson and J. Goldthorpe, The constant flux: a study of class mobility in industrial societies (Oxford, 1993).

4 The liberal professions, in medicine and law for example, are counted as elite here.

5 J. Kocka, Les bourgeoisies européennes au XIXe siècle (Paris, 1997). Much more can be said about the different sections of the middle class (see for example M. Archer, 'Small capitalism and middle-class formation in industrializing Detroit, 1880-1900', Journal of Urban History 21, 2 (1995), 218-55; M. Archer and J. Blau, 'Class formation in nineteenth-century America: the case of the middle class', Annual Review of Sociology 19 (1993), 17-41; S. Blumin, 'The hypothesis of middle-class formation in nineteenth century America: a critique and some proposals', American History Review 90, 2 (1985), 299-338). For our purpose, it is sufficient to distinguish between the new middle class of non-manual workers, farmers, and the self-employed because these are three different easy-to-distinguish types of possible marriage partners for persons from a lower-class background (since there are occupational titles in the marriage certificates).

6 G. Kurgan-Van Hentenryk and E. Chadeau, 'Structure et stratégie de la petite et moyenne entreprise depuis la révolution industrielle', in H. Van der Wee and E. Aerts eds., Debates and controversies in economic history: proceedings of the Tenth International Economic History Conference, Leuven, August 1990 (Leuven, 1990), 167-91.

7 H. Perkin, The rise of professional society: England since 1880 (London, 1989).

8 S. M. Lipset, Social mobility in industrial society (London, 1959).

9 At least until recently. Thanks to the HISCO classification of occupational titles (M. H. D. van Leeuwen, I. Maas, and A. Miles eds., HISCO : Historical International Standard Classification of Occupations (Leuven, 2002)), some attempts have been made to build comparative class schemes. See for example the SOCPO scheme used in the present article and described later in it.

10 See Erikson and Goldthorpe, The constant flux, 5, for a description of the thesis.

11 For a general discussion of societal openness, see M. H. D. van Leeuwen and I. Maas, 'Endogamy and social class in history: an overview', International Review of Social History 50, supplement 13 (2005), 1-23, and Van de Putte, Partnerkeuze. 
12 See, inter alia, overviews by M. H. D. van Leeuwen and I. Maas, 'Long-term social mobility: research agenda and a case study (Berlin, 1825-1957)', Continuity and Change 11, 3 (1996), 399-433; A. Miles, Social mobility in nineteenth- and early twentieth-century England (Basingstoke, 1999); and more recent research in M. H. D. van Leeuwen, I. Maas, and A. Miles eds., Marriage choices and class boundaries: social endogamy in history (Cambridge, 2005).

13 Van de Putte, Partnerkeuze.

14 Erikson and Goldthorpe, The constant flux.

15 M. Weber, 'Open and closed relationships', in D. B. Grusky ed., Social stratification, class, race and gender in sociological perspective (Boulder, 1994), 126-9.

16 C. Tilly, 'Demographic origins of the European proletariat', in D. Levine ed., Proletarianization and family history (Orlando, 1984).

17 B. Van de Putte and A. Miles, 'A class scheme for historical occupational data: the analysis of marital mobility in industrial cities in 19th century Flanders and England', Historical Methods 38, 2 (2005), 61-92.

18 K. Van Isacker, Mijn land in de kering, 1830-1980, Vol. I: Een ouderwetse wereld. 1830-1914 (Antwerp and Amsterdam, 1978); G. Kurgan-Van Hentenryk, 'A la recherche de la petite bourgeoisie: l'enquête orale de 1902-1904', Revue belge d'Histoire contemporaine 14, 3-4 (1983), 287-332; Serge Jaumain, 'Le petit commerce bruxellois face au Bonheur des Dames: naissance de la grande distribution et nouvelles stratégies des petits détaillants (1870-1914)', Les Cahiers de la Fonderie 3 (1987), 3-20; B. Van de Putte, 'The influence of modern city life on marriage in Ghent at the turn of the twentieth century: cultural struggle and social differentiation in demographic behaviour', Journal of Family History 32, 4 (2007), 433-58.

19 P. Delfosse, 'La petite bourgeoisie en crise et l'Etat: le cas belge (1890-1914)', Le Mouvement social 114 (1981), 85-103; G. Kurgan-Van Hentenryk, 'La petite entreprise de la fin de l'Ancien Régime à nos jours', in Petite entreprise et croissance industrielle dans le monde aux $19^{e}$ et $20^{e}$ siècles (Paris, 1981), 189-220, and 'A la recherche de la petite bourgeoisie'; M. Oris and G. Ritschard, 'Dynamique socioprofessionelle dans la Genève du $19 \mathrm{e}$ siècle, enseignement d'une analyse de statistique implicative', in R. Gras, P. Orus, B. Pinaud and P. Gregori eds., Nouveaux apports théoriques à l'analyse statistique implicative et applications: 4èmes Rencontres internationales d'Analyse statistique implicative (Castellaon, Universitat Jaume 1, 2007), 287-300.

20 F. Parkin, Class inequality and political order (London, 1972).

21 See J. Kocka, Les employés en Allemagne 1850-1980: histoire d'un groupe social (Paris, 1989), for an examination of the German case.

22 P. Hohenberg and L. Lees, The making of urban Europe, 1000-1950 (London, 1985);

E. Shorter and C. Tilly, Strikes in France, 1830-1968 (New York, 1974).

23 Van de Putte, 'The influence of modern city life'.

24 Van de Putte, Partnerkeuze.

25 See H. Kaelble, Social mobility in the 19th and 20th centuries: Europe and America in comparative perspective (Leamington Spa, 1985), especially ch. 2.

26 Literacy was connected with increased intergenerational and, to some extent, intragenerational mobility (D. Mitch, 'Literacy and mobility in rural versus urban Victorian England: evidence from linked marriage registe and census records for Birmingham and Norfolk, 1851 and 1881', University of Maryland Baltimore County Department of Economics working paper \#03-107, available at http://www.umbc.edu/ economics/wpapers/wp_03_107.pdf). Literacy was not only a tool on the labour market, it also opened alternatives to traditional behaviour (O. Boonstra, De waardij van 
eene vroege opleiding: een onderzoek naar de implicaties van het alfabetisme op het leven van inwoners van Eindhoven en omliggende gemeenten, 1800-1920 (Wageningen, 1993). Consequently, being illiterate may be associated both with the lack of valuable skills and with backwardness, and this possibly made illiteracy a strong element of stigmatization.

27 E. Le Roy Ladurie, 'La démographie des Lumières', in Le Roy Ladurie ed. La ville des temps moderns: de la Renaissance aux Révolutions (Paris, 1998), 293-348, 301.

28 B. Van de Putte, 'Homogamy by geographical origin: segregation in nineteenthcentury Flemish cities (Gent, Leuven and Aalst)', Journal of Family History 28, 3 (2003), 364-90.

29 M. Oris, 'Cultures de l'espace et cultures économiques parmi les populations urbaines liégeoises au XIXe siècle: une relecture de la problématique de l'intégration des immigrants', in Les chemins de la migration en Belgique et au Québec du XVIIe au XXe siecle (Quebec, 1995), 149-55.

30 G. Shaw, 'Recent research on the commercial structure of nineteenth century British cities', in D. Denecke and G. Shaw eds., Urban historical geography: recent progress in Britain and Germany (Cambridge, 1988), 236-49; G. Crossick and H.-G. Haupt eds., Shopkeepers and master artisans in nineteenth-century Europe (London and New York, 1984); Jaumain, 'Le petit commerce bruxellois'.

31 B. Van de Putte, 'The segmentation of the marriage market: the influence of geographical homogamy on marital mobility in 19th century Belgian cities', paper presented at the 2006 XIV International Economic History Congress (Helsinki, 21-25 August 2006). In the case of rural migrants in the nineteenth century this is likely to lead to high chances for migrant lower-class children of marrying a migrant middle-class partner - due to the high number of farmers' children among the latter.

32 A. Jacquemin, 'Alliances et reproductions sociales à Liège, 1840-1890', in G. Brunet, A. Fauve-Chamoux, and M. Oris eds, Le choix du conjoint (Paris, 1998), 107-30, especially pp. 108-9; G. Ryczkowska, 'Accès au mariage et structures de l'alliance à Genève, 1800-1880' (unpublished thesis, University of Geneva, 2003).

$33 \mathrm{~K}$. Matthijs, De mateloze negentiende eeuw: bevolking, huwelijk, gezin en sociale verandering (Leuven, 2001).

34 Remarriages, especially when involving a woman with sexual experience and a patrimony, were seen as threatening the social order. See M. Oris and E. Ochiai, 'Family crisis in the context of different family systems: frameworks and evidence on "When Dad died"', in R. Derosas and M. Oris eds., When Dad died: individuals and families coping with family stress in past societies (Berne, 2002), 17-79.

35 We have information on the occupations of brides, grooms, their fathers, their mothers, and the witnesses. However, no information is available on the deceased, and there are many missing values for women.

36 C. Vandenbroeke, 'Voedingstoestanden te Gent tijdens de eerste helft van de $19^{\text {de }}$ eeuw', Belgisch Tijdschrift voor Nieuwste Geschiedenis 4 (1973), 109-69; P. Scholliers, Wages, manufacturers and workers in the nineteenth-century factory: the Voortman cotton mills in Ghent (Oxford, 1996).

37 C. Desama and C. Bauwens, 'Une petite ville au cœur de la révolution industrielle: Verviers et le travail de la laine', in B. Van der Herten, M. Oris, and J. Rogiers eds., $L a$ Belgique industrielle en 1850: deux cents images d'un monde nouveau (Brussels, 1995), $87-128$

38 K. Van Isacker, Het Daensisme, 1893-1914 (Antwerp, 1965).

39 Jacquemin, 'Alliances et reproductions sociales'.

40 P. Bairoch, De Jéricho à Mexico: villes et économie dans l'histoire (Paris, 1985), 344. 
41 K. Matthijs, J. Van Bavel, and I. Van De Velde, Leuven in de 19de eeuw, de bevolking: een spiegel van het dagelijkse leven (Leuven, 1997).

42 Van Leeuwen, Maas, and Miles, HISCO.

43 Van de Putte and Miles, 'A class scheme'.

44 More examples and a detailed explanation of the theoretical principles and operationalizational rules can be found ibid.

45 See B. Van de Putte and A. Miles, 'Social power and class formation in the nineteenth century: how to measure class from occupation?', paper prepared for the European Social Science History Conference (Amsterdam, 2006). Furthermore, we have recently summarized our decision to use occupation as an indicator of class in A. Miles and B. Van de Putte, 'How to measure class from occupation?', paper prepared for the workshop 'The occupation in historical research' (Leuven, 2007).

46 The group of farmers is the most problematic when one uses a class scheme based on occupational titles. Another difficulty concerns 'masters', but see Van de Putte and Miles, 'A class scheme', on this.

47 The group-size variable controls for the size of the middle class among fathers of brides. This size, measured as a percentage, can be seen as the structural chance of marrying a middle-class or elite bride. Controlling for group sizes implies that we can interpret changes over time and differences between cities as changes in terms of relative mobility.

48 Some interesting variables could not be included: presence of parents in the city (not available for all cities), and father of the groom alive or deceased (no registration of occupation for deceased fathers).

49 The new variable has the following categories:

- Social origin $=$ elite, own social position $=$ elite or middle class

- Social origin $=$ elite, own social position $=$ lower class

- Social origin $=$ middle class, own social position = elite or middle class

- Social origin $=$ middle class, own social position $=$ lower class

- Social origin =lower class, own social position=elite or middle class, groom is literate, and groom is older than 28

- Social origin $=$ lower class, and is not included in the previous category.

50 Note, however, that agricultural decline and proletarianization might have led to a quantitative decrease in the size of the old middle class in the course of the nineteenth century in Aalst and Leuven (see section 4.1).

51 Van de Putte, Partnerkeuze; Van de Putte and Miles, 'A class scheme'.

52 This might mean that an elite position cannot be fully translated into upward marital mobility if one has a lower-class background. One should note, however, that the number of elite sons was very small (only 1.5 per cent of the sons of lower-class parents obtained an elite position themselves), which makes it difficult to achieve statistical significance.

53 Van de Putte, 'Homogamy'.

54 W. Sewell, 'Social mobility in a nineteenth-century European city: some findings and implications', Journal of Interdisciplinary History 7, 2 (1976), 217-33. Our results for period and location are perhaps somewhat puzzling. The findings suggest, for example, that in each city the chance of marrying upwardly was less strong than in Aalst - controlled for group size. This relationship appears only after adding the other independent variables. This means that if Aalst had not had such a low level of literacy and intergenerational mobility and so on it would have shown higher levels of intermarriage between lower-class grooms and middle-class or elite brides. 
55 Recently, the significance of social closure has been confirmed by a study using different data (population registers), which demonstrated the power and the persistence of social reproduction in nineteenth-century eastern Belgian towns, although they were growing and were substantially transformed by economic modernization. See M. Oris and G. Alter, 'Effets de fratrie et mobilité sociale intergénérationelle dans la Belgique urbaine et rurale au XIXe siècle', Annales de Démographie Historique $\mathbf{1}$ (2008), 115-38. 